\title{
University Library Buildings in the United States I890-I939
}

Miss Reynolds is assistant, Ricker Library, University of Illinois.

\section{Introduction}

$\mathrm{T}$ HIS is an historical study of university library buildings in the United States from I890 through I939. It assumes an historical development of university libraries in the United States and that the architectural development of their buildings is a necessary part of that history.

The term university includes only the members of the American Association of Universities (as of 1939). Library buildings are defined as buildings designed for the library purposes of the university and housing exclusively or primarily the university's library materials.

No buildings have been considered which were completed before 1890 or after I 939 , and the year of completion has been taken as the determining date. If built in sections, the date when the first unit was completed has been used as the key date. The period of time is assumed to be a fairly natural division of the subject matter because of evidence of a building boom in university library buildings in the I 890's and because World War II interposed a cessation of building activities in the I940's.

Thirty-eight buildings at twenty-seven universities meet the above requirements.

Planning has been emphasized rather than structure. Equipping, heating, lighting, ventilating, and furnishing of the buildings have been omitted.

Data have been drawn primarily from professional library literature and university publications. Architectural literature has recorded very little more than occasional plans. Conclusions have been derived from a study of factual data and floor plans of individual buildings, supplemented by such articles and contemporary expressions of opinion as seemed to cast light on the developments noted.

\section{Backgrounds}

University library buildings in the United States cannot be understood apart from the evolution of the university in the United States.

A real revolution in American higher education took place from I850 to I9I 7 with the rise and establishment of the university idea. As a result of this educational development, the traditional American college with its rigidly prescribed curriculum was transformed by the addition of professional schools, graduate schools, a new range of electives, and a greatly expanded curriculum. The base of education was broadened democratically with the introduction of state universities and land grant colleges. ${ }^{1}$ By I 890 the university was well established, and by 1900 the Association of American Universities had been organized. "The condition of membership was at first the maintenance of a strong graduate school, but later the effective organization of high grade professional schools in connection with the university was made a coordinate

\footnotetext{
1 W. H. Cowley, "The University in the United States of America," The University Outside Europe, edited by Edward Bradby. London, Oxford, 1939, p.
} 37 -I I 2. 
prerequisite for membership."'2 Associated with these requirements were other university ideals such as the conservation of knowledge, the extension of the bounds of knowledge by research, and the dissemination of knowledge.

Growth and change have been constant characteristics of the universities in the fifty years since 1890 . There has been an enormous expansion of university enrollments and a corresponding increase in the size of university faculties. There have been many changes in courses of study, new theories on the means of achieving educational goals, and perhaps most important of all, alterations in methods of teaching. ${ }^{3}$

The university library had changed by I 890 from a small collection of books, scarcely used and rarely added to by purchase, to a place where both students and faculty spent much time "every day consulting many authorities on subjects formerly taught from a single book." 4 From then on, the library became a laboratory of the social sciences; and this, combined with an expansion of curricular interest, the new requirement of research facilities for graduate students and faculty, and the rapid expansion of publishing output, created a continuous demand for more and more library materials. Since before World War $I$, it was recognized that the university library must continue to grow and that the growth must be unlimited, ${ }^{5}$ but it was not until well into the post-war period that study revealed the rapid rate of growth of research libraries. ${ }^{6}$ Growth had been attended by more intensive use per person, due to the change in educational methods,

${ }^{2}$ K. B. Babcock, "Universities, Association of American," A Cyclopedia of Education, edited by Paul Monroe. N.Y., Macmillan, I9I I, vol. 5, p. 682.

${ }^{3}$ W. H. Cowley, op. cit., pp. 37-I 2.

4 Kansas University, Tenth Biennial Report, I895-96. Topeka, Kansas State Print Co., I 896, p. I6. "Report of the Survey Committee," Bulletin of Brozen University 27:I33, Oct. I930.

'Fremont Rider, The Scholar and the Future of the Research Library. N.Y., Hadham, I944, p. 8. and by a greater number of persons using university libraries as the result of a democratic base of higher education in the United States. This in turn had meant an administrative growth of libraries as the volume and diversity of materials on the one hand and the volume of readers on the other have had to have progressively specialized handling.

\section{Factors Influencing the Character of University Library Buildings}

As the university library had developed in complexity, its physical form, the library building, might be expected to do likewise, influenced not only by educational methods but also by financial factors, the existence of a body of professional library opinion, the status of architectural design and building technique, and the influence of previous library buildings.

The trend of building requirements between 1890 and 1939 for university library buildings as determined by general educational factors was two-fold: a steadily increasing administrative need of a centrally located building which would afford fireproof protection and adequate facilities for the use of the university's library; and need of steadily expanding facilities for readers, storage, and administration. A centrally located building, though more accessible, could only meet the second educational requirement by being, at the outset, a much larger building than required. A building which would be flexible enough to adequately meet expansion needs would more reasonably be erected in sections over a period of time, and a location near the periphery of the campus would therefore be favored. An alleviating factor has been the tendency of universities to have both a centralized general collection and a system of college and departmental libraries.

The source of buildings funds has often 
been a factor determining whether a large building would be erected initially or whether the building would be erected sectionally. Value of ground and its availability has often determined whether expansion would be vertical or horizontal.

The influence of the university librarian and the status of library science have been important elements influencing the course followed by university library buildings. In the early I890's a few universities were without a professional librarian when library buildings were planned, and there was considerable disagreement even among librarians upon many matters of building policy. A few principles were standardized by Soule's now well-known eleven points in I 891. ${ }^{7}$ These were followed with a steady stream of publicity on individual buildings, but not until the I930's did the institutions of higher education have a statement in print of their specific standards in Gerould's College Library Building. Thus when a building was in prospect, each institution had to survey the field of accomplishment and select what seemed best. The features which were thought successful in several buildings were quite likely to be reproduced again and again-a situation very conducive to the evolution of a stereotyped pattern.

American architecture in general passed through three general phases between 1890 and 1939. The revival of the Romanesque, which was waning in the first years of the I89o's, yielded to an eclectic period about 1893, which particularly favored the classic style due to the influence of the World's Columbian Exposition. ${ }^{8}$ The eclectic period in turn gave way to the modern style about the time of World War I. However, the style of architecture in use for

7 C. C. Soule, "Points of Agreement Among Librarians as to Library Architecture." Library Journal I6:17-19, Dec, 1891 .

T. E. Tallmadge, The Story of Architecture in America. N.Y., Norton [cr936], p. 166, 234. collegiate buildings up into the I930's was influenced by the styles used between 1893 and 1917 because of a new development in the architectural treatment of colleges and universities - the campus plan. The stimulus of this movement was the plan commissioned for Stanford University in $\mathbf{I} 886$. The idea was taken up by the University of California in 1898 , and it soon gained popularity on other campuses. Consequently, the first years of the twentieth century found the style and probable location of future library buildings being preordained by the higher principle of order of the whole university community.

At the same time that logic entered the planning of entire campuses, logical planning of the individual building was developing during the I89o's and the early twentieth century. The philosophy of architects was being influenced by the Ecole de Beaux Arts in Paris as more and more American architects were imbued with the tradition of designing the interior for its function and letting the building be expressive of the design thus developed.

Building technique was at a stage in I 890 where it could respond to changing architectural demands and to the requirements of a developing library science. The introduction of skyscraper construction about I 884 had paved the way for carrying to any desired heights the stack idea which had been introduced in the United States at Harvard University in 1877. Whereas early library buildings in the United States had to plan on daylight or gaslight for the use of books, electric lighting was successfully installed in university libraries in the I880's, and its potentialities were available.

Perhaps the most powerful influence of all in determining the course which university library buildings would take was what had been attempted in previous library de- 
signs. Before 1890 some nine institutions in the United States which were later to develop as universities had built library buildings. The earliest of these was built in $\mathrm{I} 84 \mathrm{I}$ at Harvard and has been called "the conventional American library building" plan.9 Soule described it as "a churchlike interior ... adapted to library uses by shelving the bays as alcoves, and breaking their height by a gallery."10 University libraries in the United States in the I840's and I850's did not yet feel the impact of the growth problem; the alcove arrangement answered well enough for a small collection. A church-like structure suited the monumental purposes of the builders, but other monumental building types were also adapted to library use by the tieredgallery arrangement of books.

Meanwhile three famous library buildings were erected in Europe: the new Ste. Geneviève Library, Paris, I 843; the Bibliothèque Nationale, Paris, I854; and the British Museum, London, 1857. In Ste. Geneviève the reading room was on the top floor of the building with the books being stored below it; the Bibliothèque Nationale had a book stack which adjoined a large reading room; while the British Museum was a huge circular reading room surrounded by stacks. These plans were the first to deal with the problem occasioned by the enormous gains in the output of publishing houses and the necessity of providing for a larger reading public. The result was the "frank segregation of reading rooms and store rooms." 11

In the I870's and I880's the growth problem was beginning to confront a few universities in the United States. Harvard

${ }^{9}$ W. F. Poole, "The Construction of Library Buildings." Library Journal 6:69-77, Apr. 1881.

${ }^{10}$ C. C. Soule, "Library," A Dictionary of Architecture and Building, by Russell Sturgis. N.Y., Macmillan, I90I, vol. 2, col. $75 \mathrm{I}$.

11 P. P. Cret, "Library Architecture," Encyclopaedia Britannica, I 4th ed. London: Encyclopjedia Britannica Co. [cr 936], vol. 14, p. 26. first solved it by the use of a storage wing in the form of a book stack, using the same principles as the Bibliothèque Nationale. However there was by no means unanimity of opinion among librarians as to the preferred means of handling books which were separated from the reading room for storage. An opposing school of thought was led by Poole, and it held out for storage in book rooms in which book cases could be aligned in ranges, but in which a space of some eight feet was left between the top of the cases and the ceiling to insure air, light, and ventilation.

\section{A Design Problem and Its Solution: Transitional Buildings}

The university library buildings which were erected from I 890 through I 939 fall naturally into two groups, the first of which is here called transitional and includes buildings erected between $\mathrm{I} 890$ and I9IO.

Since the use of a large single room arranged on the tiered-alcove plan had fallen into disfavor and universities were being faced with growing collections and a need to administer them effectively for use, a definite commitment to the separation of readers and books was required of the transitional university library building. The design problem was that of establishing relationships between a reading room, storage unit, seminar rooms and staff rooms. The solution must also provide for a period of growth.

The transitional libraries represent experimental attempts to incorporate theories of library administration in the layout of buildings. Space will not permit here a detailed analysis of the variety of plans attempted; a summation of types will have to suffice.

There were three basic ways in which the elements of the transitional library plan 
were combined: (a) a linear arrangement with the reading room and storage element arranged in a line to form a rectangular group; (b) a centralized plan which had a square or octagonal reading room around which the other elements of the library were distributed, making a ground plan of a Greek cross, usually surmounted with a dome; (c) an angular arrangement of two wings, one containing the reading room, the other the storage element, making a ground plan of an $\mathrm{L}$ or $\mathrm{T}$, sometimes with other wings added to form an I or U.

In the linear arrangement, the reading room and the book storage element could be placed side-by-side or end-to-end. If Poole's book room storage was used, the two elements would balance well side by side, but expansion was rarely possible. If the more compact and economical stack storage was used, the stack and the reading room must be balanced asymmetrically, but the building could then usually have stack additions. An end-to-end arrangement with the entrance through the reading room put the stack at the rear of the building where it could conveniently be expanded, but this arrangement meant traffic through the reading room. Seminars could easily be located on upper floors of the library, but staff work rooms which needed to be near the circulation desk were pressed for space in each type of linear building.

The domed buildings met the need for flexibility and expansion even less successfully, and from the point of view of use the reading rooms were often disturbed by traffic.

The angular solutions were by far the most satisfactory. The $\mathrm{L}$ arrangement had good points, but the $T$ offered more possibility for expansion and adaptation. The most successful use of the $T$ was the same general plan as that later exploited by the Carnegie libraries: a reading room wing was adjoined at the rear center by a stack wing. The entrance at the center of the reading room wing opened into a delivery hall to the left and right of which were reading rooms, and straight ahead was the loan desk in direct contact with the stack.

As a class the transitional buildings had certain features in common. The main reading room, book room or stack, and loan desk were almost always on the floor to which the reader was admitted. This was usually the first floor. A definite separation of loan activities from the reading room was an exception rather than the rule, although there was a distinct tendency in that direction. In orientation of book storage to the main floor of the library, the first tendency was to have the first tier of stack or the first floor of book rooms on the level with the reading room. With the increasing popularity of the stack arrangement, it was soon discovered to be an advantage if the middle tier of the stack could coincide with the reading room floor level. In practical terms this meant less distance to be traversed vertically from the delivery desk. This was accomplished by using a sloping site, or by elevating the main floor above ground and using a monumental stair.

A very strong tendency can be remarked to house in the library building educational activities which had no relation to library work due to the necessity for building bigger libraries at the outset than would be actually needed for several years.

On the whole the type of plans selected were more likely to be based on the traditional plans for monumental buildings, which would afford opportunities for towers, buttresses, domes, columns, etc. The experimental attempts to introduce planning based on needs may be regarded as the development of the delivery room, the orientation of the mid-stack tier to the loan 
desk level, and the development of the angular plan.

\section{A Design Problem and Its Solution: Modern Buildings}

The university library buildings here designated as the modern group include those erected between I9II and 1939. They form (with two exceptions) a closely related group exhibiting elaborations of the basic $T$ plan of transitional buildings. Two variable factors appear throughout the group: (a) the building was compact in plan or it was opened up by light courts, and (b) the stack was at the rear of the building or it was the central core of the building.

The University of Texas Library, I9I I, was the earliest example. A rear-stack building of moderate size, it shows clearly the relation to the $T$ type of transitional building. The reading room was at the front of the building and separated from the stack by a delivery room, the administrative rooms of the library, and the single stair. The disposition of the elements was not different from the transitional $\mathrm{T}$, but the whole arrangement had been moved to the second floor, which permitted the entrance to be in the center of the main wing while a single large reading room was obtained in a location removed from the noise of the entrance.

To this basic arrangement the University of California, 1912, added lateral and rear wings to surround a stack lighted from above as at the Bibliothèque Nationale, Paris. The delivery hall was expanded, and the staff rooms moved into a location in one of the lateral wings. The building was erected in two separate stages, and by the time it was completed in 191 7 a differentiation of readers had been created: undergraduate reserve, general and graduate on the first, second, and third floors, respectively. This was the prototype arrange- ment which subsequent university library buildings followed.

The first open plan was Gilman Hall, Johns Hopkins, 1914. Basically a reversed prototype, it had the stack split by a light court in order that graduate research might be carried on with all the books immediately at hand. The principle of definite provision for graduate work in the stack was furthered at Harvard, I9I5, where individual stalls lined each outside wall of an open quadrangular stack.

Four of the remaining university library buildings had compact building plans and eleven others were designed with open plans; but only one of the compact buildings, and only two of the open plans were designed with a completely enclosed stack. The reason may be found partly in the fact that all of the university library buildings erected after the Harvard building made provision for cubicles or something similar in the stacks. Daylight was important for such use, and could be achieved by a rear stack or by light courts introduced between the stack and the lateral wings or between the stack and the reading room wing. Theoretically, site and architectural treatment of the building permitting, the library erected with stack at the rear, as the first unit of the University of California building showed, could expand both stack and lateral wings, and finally completely enclose the stack to make the building a compact whole. Perhaps all rear stack buildings ought to be regarded as still incomplete realizations of the fullest use of their possibilities in the development of a rectangular building.

In the 1930's a few buildings began to appear which utilized a tower stack. The Yale University building of 193 I was one of the two modern buildings to depart from the prototype plan. Its distinctive feature was organization on a single level at the base of a stack which formed a tower. The 
University of Texas building, 1933, incorporated a tower stack with an open prototype plan. It remained for South $\mathrm{Hall}$, Columbia University ${ }^{12}$ to use a stack which projected above the rest of the building as a solution which permitted a compact base and still would permit the periphery of the stacks in the tower to be used for study purposes.

The modern university library buildings have developed along principles of physical organization which were inherent in the $T$ plan as used at the University of 'Texas and in the rectangular plan used for the Bibliothèque Nationale in Paris. The main reading room, delivery hall, and entrance to the stacks occupied a position on one of the floors above the first. 'This was usually the second floor, although occasionally in late buildings it was higher. On the same floor level with the reading room, delivery hall, etc., one of the lateral wings of the building contained additional reading rooms, and in the other lateral wing was usually to be found one of the administrative units of the library. The first floor of the building was the favored location for reserved book rooms and the location to which the administrative quarters were withdrawn when they did not occur on the same floor level with the delivery hall. The floors above the main reading room generally contained the provisions for graduate reading rooms, seminars, studies, etc.

The tendency has been to centralize the stack with reading and work rooms distributed around its periphery. This was completely realized in central-stack buildings and only partially so in rear-stack buildings.

\section{The Planning of Particular Elements}

In addition to the design problem of establishing relationships, much planning has gone into the three specific provisions

\footnotetext{
12 Now known as Butler Library.
}

of the library: the accommodation of the library's collection, the accommodation of readers, and the provision for the administrative element of the library.

For several years after 1890 there were both book rooms and stacks, but after 1903 stack construction had won out in the planning of university library buildings for by then the stack structure had been considerably refined. The first stacks in transitional buildings showed experimental attempts to perfect lighting by trying to ensnare as much daylight as possible. As the technique of handling electricity improved, the necessity for daylight to enable books to be found diminished, although the desirability of daylight for graduate study became a separate problem.

The principles of university library growth were not fully understood when the transitional buildings were planned, but there was another factor which caused serious overcrowding of many a building before it was a decade old: the method of gauging capacity. Henderson has traced the evolution of library science on this point from the I880's into the I930's. ${ }^{13}$ For university library buildings capacity was being figured at eight books per lineal foot in I 890 , but the standard was progressively lowered until a figure of five books per lineal foot of shelving was being used in 1931. The cubook developed by Henderson was used in figuring the capacity of Columbia's South Hall in 1934.

The factor of diverse types of material had also to be reckoned and was closely related to specialized service to readers. Special stacking was developed for newspapers from about I9I9. Maps and rare books were stored in separate rooms from about the same period. Only the most recent of university libraries had planned provision for storing photographic film.

${ }^{13} \mathrm{R}$. W. Henderson, "The Cubook: a Suggested Unit for Book Stack Measurement." Library Journal 59: $865-68$, Nov. I 5 , 1934 . 
In planning the library buildings for the use of readers, the principal development between I 890 and 1939 was probably provision for increasing numbers of readers. Data on standards employed in planning are meager and conspicuous by their absence up to about 1920. The University of California must have planned for not more than ten per cent of the student body. By 1919 it was considered necessary to plan the University of Michigan Library to take care of about twenty per cent of the enrollment, and the ration of seats to readers was raised to a third by the University of North Carolina in 1929.

Growth was accompanied by gradual differentiation between service areas. The transitional buildings were fairly uniform in their provisions: loan, reference, and periodical service were all in the general reading room. Occasionally periodicals, and sometimes newspapers, were put in a separate room. For readers permitted to enter the stacks, there were a few tables, and there was scarcely a transitional building which did not pride itself on the number of its seminar rooms. In the modern buildings reserved book reading rooms were found to be a requirement by 1920 , and the recreational reading room was appearing. The periodical room had also become a separate division. Consequently the main reading room became a general reading and reference room. Between I9II and 1920 the principle of individual study units in the stack for advanced students and faculty researchers was developed, and the seminar collections of the transitional buildings became a graduate reading room with small adjacent rooms for actual class meetings.

The whole trend in providing for both books and readers has been a growth from simple provisions for a rather homogeneous body of readers to complex provisions for definitely classified readers.
There has been corresponding change in the provision for the administration of university libraries. In the earliest of the transitional buildings, the librarian's office was located adjacent to the delivery desk and in direct or very close contact with the small cataloging room. Receiving rooms were almost always located directly beneath the cataloging room. The catalog was usually located where it was equally accessible to the catalog room and to readers.

In the modern group of buildings, the administrative departments needed larger quarters and the tendency was for them to withdraw to one of the lateral wings of the prototype building, with the librarian's office even more withdrawn from lines of traffic but accessible to administrative departments. Work rooms which were at first somewhat small and partitioned off have developed uniformly to be large rooms lacking fixed partitions. As with the planning of accommodations for readers, data on the standards employed in planning the amount of floor space required for administrative departments are almost non-existent, and it has not been possible to determine what standards were used in the specific buildings studied.

\section{Conclusions}

Between I 890 and 1939 university library buildings have shown a very remarkable development, the buildings ranging from comparatively simple structures in which the library occupied principally one floor, to the complex buildings of the thirties, of several floors and with stacks up to twentyeight tiers in height. The extremes of the development suggest a course of evolution.

The first stage is to be sought among the angular $T$ type transitional buildings. This type should be regarded as one of the several experimental efforts in combining the separated reading and storage elements 
of the library and as a necessary adjustment to such factors as the following.

The reading room was traditionally the important element of the university library plan. The first stacks in transitional buildings occupied a relatively small area in comparison to the reading room; and by reason of the fact that it was necessary to give the stack special architectural treatment, the two elements would not balance well if used side-by-side. Nor had an endto-end arrangement been successful because of the traffic which had been brought through the reading room. On the other hand, the stack needed to be in close contact with the reading room for a successful plan. There was also the growing realization of the need of a delivery room separate from the reading room and of the need of planning the building for expansion. The $T$ plan was the solution which seemed to combine most successfully all these needs.

The next stage is to be found in the University of Texas Library, I9I I. Rising enrollments and increased use of the library made larger reading rooms desirable, and they could be obtained with a $\mathrm{T}$ plan only by putting them on the second floor, where they gained in light and in freedom from the noises associated with the main entrance. Separation of loan activities from the reading room could be gained by introducing the delivery hall and stair hall between the reading room and the stack.

With the University of California building, the pattern of development for the subsequent university library buildings was definitely set. To the basic $\mathrm{T}$ plan of the University of Texas were added lateral and rear wings which completely surrounded the stack, making it the central focus of the building. The administrative rooms, which were formerly centered near the loan desk, gravitated naturally into a lateral wing of the building, and at the same time the still unsatiated demand for reading room space expanded reading rooms into the other lateral wing. The administrative need for differentiating services to readers found ready use now for rooms on the first floor to satisfy the needs of the numbers of students doing required reading, while seminars and other graduate facilities found more seclusion on the top floor of the building.

Although the prototype was established, it was amenable to adaptation and responsive to new educational ideas, and these two qualities were to delay the mote logical development of university library buildings as compact buildings making the greatest use of the advances in building technique. The specific factors which influenced library buildings at this stage were the prosecution of campus plans and the development of the idea of individual cubicles in the stacks. The first of these factors encouraged horizontal rather than vertical expansion, and the second factor invited the introduction of light courts. Gilman Hall is the prime example of the latter tendency.

The final stage of the evolution is found in those buildings which have developed the stack as a tower. This was first tentatively combined with open plans, as at Yale University and the University of Texas. However, with the tower resolving the problem of providing light along the periphery of the stacks for cubicles, the compact plan which had the stacks as the core of the building was resumed in South Hall, Columbia University, which may be regarded as the highest development of the prototype plan.

These conclusions are based on an isolated study of the university library building, and it must be recognized that as only a small section of the total body of library architecture in the United States, university library buildings did not develop in an iso-

(Continued on page r66) 
loan privileges. By making the material easier to obtain and withdraw, it was believed that these hours would be satisfactory. This seems to be the case.

In order to obtain the student reaction to these variants from the policy of the main university library, and also to obtain their reactions to the library in general, a short questionnaire was submitted to sample classes of students towards the end of the spring quarter. The results were both helpful and gratifying.

Eighty-nine per cent of the students approved the service schedule and observed that the more generous loan privileges of reserve and non-reserve material made it unnecessary to visit the library evenings or Saturdays.

Eighty-two per cent of the students in these classes (which also contained some juniors and seniors) had used the library, and over one-half used it at least once a week. The results seem to reveal that those who do use the freshman-sophomore library, use it more than they do the main library, even though the freshman-sophomore library contains only books.

The main complaint mentioned in the replies was that the library was not open to general use by all students as it was to the freshmen and sophomores. This is because upperclassmen are encouraged to borrow books from the main library which does have other copies of most titles stocked in the freshman-sophomore library.

This then is a beginning at Minnesota toward bringing undergraduate students into closer contact with library materials. The present intention is to keep a moderately sized but active collection on hand within each department area. Books superseded or no longer useful will be withdrawn and replaced by newer material, with research playing no part of this library's objective. In line with this objective, loans from the freshman-sophomore library are not made to faculty or staff members of the university, but only to students.

There has been a strenuous attempt at streamlining records and files and it has allowed the library to be staffed lightly and yet to give service to patrons. By means of tickler files, carbon insert circulation forms, and other time saving forms, our records are simple to maintain, yet sufficient and accurate.

It appears that the library has been relatively successful. There are many small problems to be ironed out, but with modifications and changes as time goes by, together with the allowance for new developments, it should definitely prove an excellent as well as an economical way of bringing student and book together.

\section{University Library Buildings (Continued from page 157)}

lated environment. Further study of the libraries of institutions of higher education in the United States, of the public libraries in the United States, and even of the libraries of other countries would be needed to fill out the picture.
The study of university library buildings built in the United States between I84I and I 889 would also have a great deal to add to both the history of university library architecture and perhaps to the history of architectural development in the nation. 